American J. of Engineering and Applied Sciences 4 (2): 201-208, 2011

ISSN 1941-7020

(C) 2011 Science Publications

\title{
Use of Recycled Aggregate and Fly Ash in Concrete Pavement
}

\author{
Myle Nguyen James, Wonchang Choi and Taher Abu-Lebdeh \\ Department of Civil, Architectural and Environmental Engineering, \\ North Carolina A and T State University, Greensboro, North Carolina, USA
}

\begin{abstract}
Problem statement: Recycled materials aggregate from the demolished concrete structures and fly ash from burning coal shows the possible application as structural and non structural components in concrete structures. This research aims to evaluate the feasibility of using concrete containing recycled concrete aggregate and fly ash in concrete pavement. Approach: Two water cement ratio ( 0.45 and 0.55$)$ the compressive strength, modulus of electricity and flexural strength for concrete with recycled aggregate and fly ash with $0,25 \%$ replacing cement in mass were considered. Results: The material properties of recycled aggregate concrete with fly ash indicate comparable results with that of concrete with natural aggregate and without fly ash. Conclusion/Recommendations: The recycled materials could be used in concrete pavement and it will promote the sustainability of concrete.
\end{abstract}

Key words: Recycled aggregate, fly ash, compressive strength, elastic modulus, concrete pavement, recycled materials, flexural strength, concrete structures, reinforced concrete

\section{INTRODUCTION}

The large volumetric in-waste or by-product materials from industry are going to landfills and have been increasing with time. Recycling and reusing of construction waste is a viable option in construction waste management. Rawshan et al. (2010) investigated the effect of prefabrications in building systems in reducing waste. They showed that large amount of material wastage can be reduced by the adoption of prefabrication and revealed that the rates of reused and recycled waste materials are relatively higher in projects that adopt prefabrication. Kumaran et al. (2008) investigated the feasibility of using waste tires (chips and fibers) in concrete to improve its strength. They outline the use of rubberized concrete in structural and non-structural members and show how it is suitable for the concrete and its uses.

Sustainable materials are one of the strategies to be considered by the construction industry to help circumvent waste problem. A couple of ways to achieve the goal of reducing volumetric in-waste is to introduce Recycled Concrete Aggregate (RCA) from the largest sources of such waste such as construction and demolition projects and Fly Ash (FA) from burning coal into the production of concrete. This is the primary impetus for the recycled materials of concrete pavement in the form of RCA and FA and has become an obvious choice for concrete pavement. The advantages of using RCA and FA are of economic and environmental concern. The potential for the use of Recycled Concrete Aggregate (RCA) has been explored previously, but its use with Fly Ash (FA) in concrete pavement has not been thoroughly studied. Subsequently there is a need to assess the performance of RCA with fly ash for use in concrete pavement.

The application of Recycled Concrete Aggregate (RCA) in concrete started in the U.S. in 1942 by using demolished concrete pavement as recycled aggregate for stabilizing the base materials for road construction. In general, the RCA has high water absorption due to the cement paste from old concrete. It will result in the inferior material properties of recycled aggregate concrete. Presently, the mix design with RCA was developed to get the desired material properties by the earlier studies. A significant number of studies have been done on recycled aggregate. Roshan et al. (2010) studied special type of light weight aggregate (lika) to achieve the best mix design of light weight concrete and to optimize the amount of Micro Silica in a light weight lika concrete. Ahmed and Mihashi (2009) conducted an experimental study on restrained shrinkage of cement mortar and light weight High

Corresponding Author: Myle Nguyen James, Department of Civil, Architectural and Environmental Engineering, North Carolina A and T State University, 1601 E. Market Street, Greensboro, North Carolina, USA Tel: (336) 334-7737 Fax: (336) 334-7126 
Performance Fiber Reinforced Cementitious Composites (HPFRCC). They observed that the higher number of multiple cracks with small cracks width in light weight HPFRCC specimens due to drying shrinkage was due to their strain hardening and ductile behavior compared to quasi brittle behavior of premix mortar where less number of wide cracks was observed. Chandramouli et al. (2010) presented a study on the influence of fiber content on the durability performance of glass fibre reinforced concrete. They investigated rapid chloride permeability and concluded that addition of glass fibres improves that durability performance appreciably.

The workability of mixes made with RCA can be improved by adding FA as partial cement replacement and using water reducing agents. Ramli and Hoe (2010) studied the effect of different fibers on the mechanical properties of High Strength Concrete (HSC) containing fly Ash. They discussed the effects of incorporated short discrete Coconut Fibers (CF), Barchip Fibers (BF) and Glass Fibers (GF) into HSC to enhance the performance of concrete. Their results show that all of the fibrous specimens had lower density than control. However, the compressive strength of the HSC had increased from 71.8-79.0 MPa using $1.8 \%$ of BF while flexural strength had increased from 5.21-6.50 MPa. Qadi et al. (2009) developed Statistical models to model the influence of key mixture parameter such as cement and fly ash on hardened properties affecting the performance of Self-Compacting Concrete (SCC). Their results presented numerical models that can be useful to reduce the test procedures and trials needed for the proportioning of self-compacting concrete. Sathyabalane investigated hybrid LM6 aluminium alloy Metal Matrix Composites (MMC) with flyash and SiC and studied the effect of the four parameters, size and weight of the reinforcements on the hardness and wear loss. Hoe and Ramli (2010) investigated the production of High Strength Concrete using materials with high fineness modulus. They tested concrete from 15 mixes where high strength of more than $65 \mathrm{MPa}$ was achieved.

The input parameters required for critical response computation with use of the Mechanistic-Empirical Design Guide of new and rehabilitated pavement structures are: Elastic modulus, Poisson's ratio and modulus of rupture (Nagaradjane et al., 2009; Saravanan et al., 2010; Sirimontree and Teerawong, 2010; Ravichandran et al., 2009; Maghsoudi and Sharifi, 2008; Hamoush et al., 2011). Kumar and Vidivelli (2010) discussed the benefits of using
Ferrocement in enhancing the overall performance of Reinforced Concrete (RC) structures and in increasing the flexural strength of deficient reinforced concrete members. They concluded that acrylic rubber latex modified ferrocement is a doable alternative strengthening component for the rehabilitation of reinforced concrete structures. Bekoe et al. (2010) reported that concrete made with RCA has slightly lower compressive strength, flexural strength and modulus elasticity. In earlier research studies involving concrete for use in pavement, he reported that the optimal concrete mixture for concrete pavement was not necessarily a concrete with a high flexural strength, but a concrete with the proper combination of low modulus of elasticity, low coefficient of thermal expansion and adequate flexural strength. The attributes of concrete containing FA and RCA are conciliatory to the characteristics necessary for pavement concretes. Therefore, incorporation of RCA and FA in concrete can reduce the modulus of elasticity of concrete mixtures and subsequently can reduce the load-induced stresses in concrete pavements. Addition of RCA to concrete can reduce the stress-strength ratio and thus improve the performance of concrete pavement under load conditions. The FA has been approved for use as a replacement of cement to make durable and workable concrete with low drying shrinkage and lower heat evolution during hydration (Anderson et al., 2009).

The objective of this study is to evaluate material properties of concrete containing varying amounts FA and/or RCA. Compressive strength in the context of this application is a measure of the concrete to withstand cracking when a large concentrated load is applied and concrete must have an adequate elastic modulus such that it does not pit when a large, cyclic, concentrated load is applied. One of the common characteristics of an older concrete road is pits caused by moderate, localized, cyclic compressive stresses. These pits in turn lead to one of several common failure mechanisms such as several forms of cracking (e.g., freeze cracking, corrosion cracking) (Anderson et al., 2009). Finally, flexural strength of the concrete is a measure of the concrete's ability to resist flexing when a large, distributed load is applied over a length of the concrete. If the concrete flexes too much for a given segment, then the concrete will have to be thicker such that it does not fail by tensional stresses on the underside of the slab of concrete. 
Am. J. Engg. \& Applied Sci., 4 (2): 201-208, 2011

\section{MATERIALS AND METHODS}

The physical properties of density and strength of concrete are determined by the proportions of the three key ingredients: Water, cement and aggregate. Portland cement type I and Fly ash Class F are supplied by local ready mix company located in Greensboro North Carolina. Fine aggregate and \#57 coarse aggregate was used in this study. Virgin aggregate was tested to determine its specific gravity, water absorption gradation and LA (abrasion loss). RCA was obtained from a stockpile of Recycled Material in Charlotte NC. Table 1 presents RCA's specific gravity, water absorption gradation and LA and compared with natural coarse and fine aggregate.

The experiments require that the RCA must be washed in order to evaluate the water absorption for proper water,cement ratio determination (Mehta and Monteiro, 2006). Materials such as aggregates and sand must go through a sieve analysis in order to have the required particles grade size according to the desired texture design. The initial quantity measurements for each material must be taken for the specific mix design either by volume. Detailed sieve analysis for both virgin and recycled aggregate are presented in Table 2.

The water/cement ratio is the most critical part of controlling the concrete strength. Hansen (1999) concluded that the w/c ratio is valid for recycled aggregate concrete as it is for concrete made with virgin materials, but only the level of strength development would be reduced. The design compressive strength in this study are $4500,5500 \mathrm{psi}$, which is commonly used concrete compressive strength in concrete pavement. The w/c ratio are 0.55 and 0.45 , respectively. The mix proportions for these mixes are shown in Table 3.

For each concrete mixes, cylindrical specimen $(4 " \times 8 ")$ and prismatic beams $(6 " \times 6 " \times 21 ")$ were used to determine compressive strength, elastic modulus and flexural strength. To consider long term properties due to containing FA, the first batch mainly used for short term properties (age of 14, 28 and 56 days). Second batch was used for long term properties (age of 56, 72 and 112 days) with w/c ratio of 0.55 in Type 1 specimens. With reducing the water cement ratio of 0.45 , the long term properties (age of 56, 72, 112 days) was measured for Type 2 specimens. After placing concrete into the plastic molds, the molds were stripped after $24 \mathrm{~h}$. and place specimens in a water tank to cure up to the required age for testing.
Table 1: Specific gravity and water absorption (Bekoe et al., 2010)

\begin{tabular}{lllc}
\hline Constituents & $\begin{array}{l}\text { Coarse } \\
\text { aggregate }\end{array}$ & $\begin{array}{l}\text { Fine } \\
\text { aggregate }\end{array}$ & Coarse RCA \\
\hline $\begin{array}{l}\text { SSD specific gravity } \\
\begin{array}{l}\text { Dry bulk specific } \\
\text { gravity }\end{array}\end{array}$ & 2.73 & 2.64 & 2.34 \\
$\begin{array}{l}\text { Dry apparent specific } \\
\text { gravity }\end{array}$ & 2.53 & 2.63 & 2.19 \\
$\begin{array}{l}\text { Absorption (\%) } \\
\text { LA abrasion loss }\end{array}$ & 4.00 & 2.65 & 2.58 \\
\hline
\end{tabular}

Fresh concrete: Along with the specimens, some portion of concretes was taken out to conducting slump test and temperature for each mix. Table 4 presents tests results performed on the fresh concrete used in this study. A slump test and unit weight was measured in accordance with ASTM C143 and ASTM C138, respectively. A temperature reading was taken in accordance with the ASTM C1064 procedure to measure the temperature of freshly mixed concrete and around $80 \sim 85^{\circ} \mathrm{F}$. Consistent results were obtained for each mixes regardless containing RCA and FA.

Compressive strength: The standard ASTM C-39 test procedure was followed in running the compressive strength on the 4" $\times 8$ " cylindrical specimens. The ends of the specimen were capped before testing to ensure even loading during test. The diameter of each specimen was taken before placing it in a Forney material testing machine with a maximum capacity of 400kips. Load was applied to the specimen at a loading rate of $10-15 \mathrm{psi} / \mathrm{s}$ until complete failure occurred. The outputs of the load cell from the testing machine were connected to a data acquisition system, which records the data during the test. The maximum load is recorded and the compressive stress computed by dividing the maximum load by the cross sectional area of the specimen. The type of fracture for each cylinder was also recorded during the testing. Similar failure modes were observed in the tests.

Elastic modulus test: Calibration of the Linear Variable Displacement Transformer (LVDT) gage that holds linear variable differential transformer is required. The gage is mounted to the test specimen at two points between which displacement is to be measured.

The standard ASTM C469 test procedure was followed in running the elastic modulus test on the " $4 \times 8$ " cylindrical specimens. The ends of the specimen were capped as usual before testing to ensure even loading during the test. Two 4-inch displacement gages, held by four springs were mounted on the sides of the specimen. Load was applied to the specimen at a loading rate of $10-15 \mathrm{psi} / \mathrm{s}$ until $40 \%$ of the maximum compressive load was obtained. 
Am. J. Engg. \& Applied Sci., 4 (2): 201-208, 2011

Table 2: Results of sieve analysis (Bekoe et al., 2010)

\begin{tabular}{lllll}
\hline Sieve size & $\begin{array}{l}\text { Sieve size } \\
(\mathrm{mm})\end{array}$ & $(\%)$ Passing & (\%) Passing & $\begin{array}{c}(\%) \text { Passing } \\
\text { Coarse RCA }\end{array}$ \\
\hline 1.5 in. & 37.0 & Coarse aggregates & Fine aggregates & 100 \\
1 in. & 25.0 & 100 & $/$ & 96 \\
$1 / 2$ in. & 12.5 & 100 & $/$ & 60 \\
No. 4 & 4.75 & 50 & 1 & 10 \\
No. 8 & 2.36 & 7 & 98 & 4 \\
No.16 & 1.18 & 4 & 87 & $/$ \\
No. 30 & 0.60 & $/$ & 64 & $/$ \\
No. 50 & 1 & $/$ & 35 & $/$ \\
No. 100 & 0.30 & $/$ & 7 & \\
\hline
\end{tabular}

Table 3: Concrete mixes for each type

\begin{tabular}{llllllll}
\hline Type & w/c ratio & $\begin{array}{l}\text { Water, } \\
\mathrm{lb} \mathrm{yd}^{-3}\end{array}$ & $\begin{array}{l}\text { Cement } \\
\mathrm{b} \mathrm{yd}^{-3}\end{array}$ & $\begin{array}{l}\text { FA } \\
\mathrm{lb} \mathrm{yd}^{-3}\end{array}$ & $\begin{array}{l}\text { Coarse aggregate } \\
\mathrm{lb} \mathrm{yd}^{-3}\end{array}$ & $\begin{array}{l}\text { Fine aggregate } \\
\mathrm{lb} \mathrm{yd}^{-3}\end{array}$ & $\begin{array}{l}\text { Coarse RCA } \\
\mathrm{lb} \mathrm{yd}^{-3}\end{array}$ \\
\hline 1 & 0.50 & 280 & 560 & 0 & 1765 & 1237 & 0 \\
& 0.55 & 280 & 510 & 0 & 1324 & 1237 & 441 \\
\\
0.55 & 280 & 459 & 51 & 1324 & 1237 & 441 \\
& 0.55 & 280 & 410 & 77 & 1324 & 1237 & 441 \\
& 0.40 & 280 & 700 & 0 & 1665 & 1211 & 0 \\
\\
0.45 & 280 & 620 & 0 & 1248 & 1211 & 417 \\
& 0.45 & 280 & 558 & 62 & 1248 & 1211 & 417 \\
& 0.45 & 280 & 527 & 93 & 1248 & 1211 & 417 \\
\hline
\end{tabular}

Table 4: Properties of fresh concrete

\begin{tabular}{|c|c|c|c|c|c|}
\hline Type & Mix ID & Slump (in) & Unit Weight $\left(\mathrm{lb} \mathrm{ft}+{ }^{3}\right)$ & Air Content (\%) & Temperature, $\left(\mathrm{F}^{\circ}\right)$ \\
\hline \multirow[t]{4}{*}{1} & 0.5 R0-F0 & 2.50 & 148.0 & 1.50 & 82 \\
\hline & 0.55 R25-F0 & 2.75 & 149.0 & 1.25 & 80 \\
\hline & $0.55 \mathrm{R} 25-\mathrm{F} 10$ & 2.50 & 149.5 & 1.25 & 81 \\
\hline & $0.55 \mathrm{R} 25-\mathrm{F} 15$ & 2.50 & 149.0 & 1.25 & 84 \\
\hline \multirow[t]{4}{*}{2} & $0.4 \mathrm{R} 0-\mathrm{F} 0$ & 2.75 & 149.5 & 1.25 & 85 \\
\hline & 0.45 R25-F0 & 2.50 & 148.5 & 1.50 & 82 \\
\hline & $0.45 \mathrm{R} 25-\mathrm{F} 10$ & 2.50 & 149.0 & 1.25 & 84 \\
\hline & $0.45 \mathrm{R} 25-\mathrm{F} 15$ & 3.00 & 149.5 & 1.25 & 85 \\
\hline
\end{tabular}

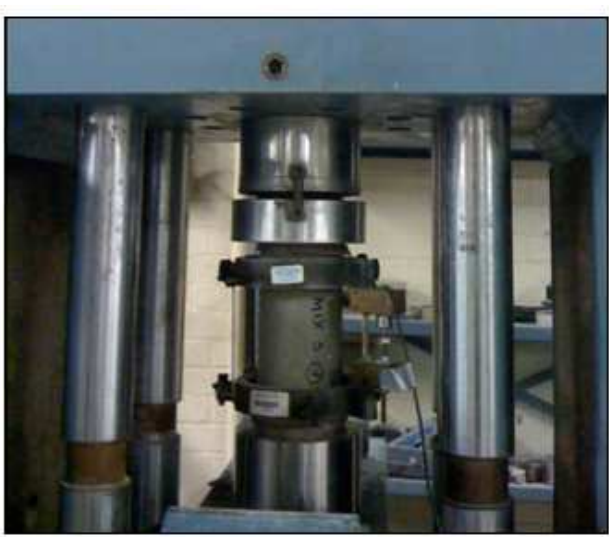

(a)

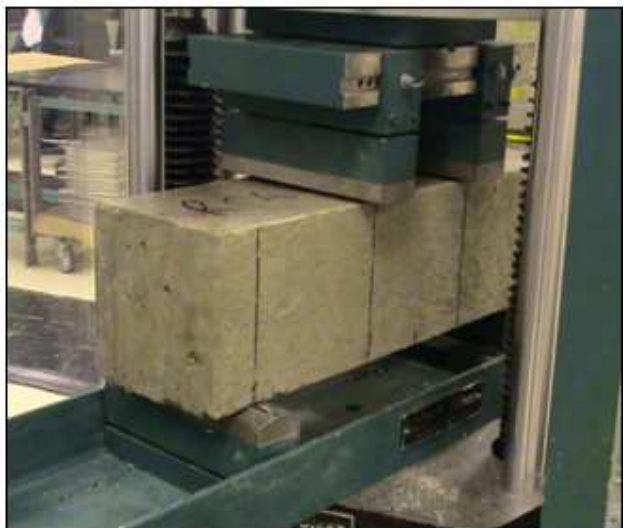

(b)

Fig. 1: Test set-up (a) Compressive strength and elastic modulus; (b) Flexural test setup

The outputs of the displacement gages and the load cell from the testing machine were connected to a data acquisition system, which records the data during the test. The cylinders for the modulus of elasticity test were cycled to $40 \%$, three times. The data from the first load cycle on each specimen were disregarded. The average value from the last two times was recorded as the elastic modulus of the concrete. The average lateral displacement reading was also used to calculate the strain and the reading from the load cell was used to calculate the stress during the testing of this research. Typical test set-up is shown in Fig. 1a. 
Flexural strength test: Before each beam is placed in the testing machine, draw a reference line on the top and bottom of the beam, as cast, about 1.5 in from each end of the specimen. The two reference lines should be exactly opposite each other. The two loading surfaces were ground even with a stone to ensure that the applied load was uniform. Measure specimens after the test as follows: Take three measurements across each dimension, one at each edge and one at the center of the specimen at the section of failure. Round each measurement to the nearest 0.05in. These measurements are to determine the average width, average depth and line of fracture location. Figure $1 \mathrm{~b}$ shows the beam in testing progress. The flexural strength test was run in accordance with ASTM C78 for each cure age and the average strength was computed.

\section{RESULTS}

Effect of RCA and FA on compressive strength: Table 5 shows the compressive strength for each mixes. The specimens with 14 days in Type 1 the compressive strength decreases by $1.7,0.8$ and $4.1 \%$ respectively for the three concrete mixtures: ID 0.55 R25-F0, 0.55 R25F10,0.55 R25-F15 as compared with the 0.55 control mix. Similar results also observed in the Type 2 mixes with the water cement ratio of 0.45 .

Effect of RCA and FA on modulus of elasticity: Table 6 present the results of the elastic modulus test. At short cure durations, it can be seen that there is an initial reduction in the elastic modulus of concrete in the concrete mixtures containing RCA and varying amounts of FA.

Batch I-Type I, at a fixed 0.55 water/cement ratio and a cure time of 14 days, the elastic modulus decreases by $4.1,4.1$ and $3.3 \%$ respectively for the three concrete mixtures: ID 0.55 R25-F0, 0.55 R25-F10 and $0.55 \mathrm{R} 25-\mathrm{F} 15$ as compared with the control mix. At 28 and 56 days, the elastic modulus remains unchanged for concrete mixture ID $0.55 \mathrm{R} 25-\mathrm{F} 0$ and is lower by $0.5 \%$ for the two concrete mixtures: ID 0.55 R25-F10 and 0.55 R25-F15 respectively as compared with the control mix. This shows that concrete mixtures containing $10,15 \%$ FA exhibit a decrease in elastic modulus of $0.5 \%$ when compared with concrete mixtures containing RCA only for shorter cure durations. The results indicate that three concrete mixtures with ID: 0.55 R25-F0, 0.55 R25-F10 and 0.55 R25-F15 have a lower elastic modulus at 14 days when compared to the control mix.

At 28,56 days, concrete mixtures containing only RCA have the same elastic modulus. Concrete mixtures containing $10,15 \%$ FA have a slightly lower elastic modulus as compared with the control mix. At 72,112 days, the elastic modulus is the same as concrete mixtures ID $0.55 \mathrm{R} 25-\mathrm{F} 0$ and is lower by $0.2 \%$ for concrete mixtures with ID 0.55 R25-F10 and 0.55 R25-F15 as compared with the control mix. Table 6 indicates that three concrete mixtures with ID $0.55 \mathrm{R} 25-\mathrm{F} 0$ have the same elastic modulus after 56 days of cure duration. The concrete mixtures with ID 0.55 R25-F10, 0.55 R25-F15 had slightly lower values for elastic modulus after 56 days of age, as compared to the control mix. Similar resutls were measured for Type 2 with the water cement ratio of 0.45 .

The elastic modulus was compared with the predicted equations in ACI 318 (2008) $\left(E_{c}=33 \cdot w_{c} \sqrt[1.5]{f_{c}^{\prime}}, p s i\right)$ as seen in Fig. 2. The predicted values overestimated the experimental results regardless containing RCA and FA in the concrete mixes.

Table 5: Average compressive strength

\begin{tabular}{|c|c|c|c|c|c|}
\hline Type & Batch & ID. & 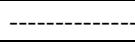 & sive strength & - \\
\hline & & & At 14 days & At 28 days & At 56 days \\
\hline 1 & 1 & 0.50 Control & 4520 & 4836 & 5122 \\
\hline & & 0.55 R25-F0 & 4443 & 4711 & 5089 \\
\hline & & 0.55 R25-F10 & 4480 & 4789 & 5195 \\
\hline & & 0.55 R25-F15 & 4344 & 4790 & 5203 \\
\hline & 2 & & At 56 days & At 72 days & At 112 days \\
\hline & & 0.50 Control & 5178 & 5180 & 5190 \\
\hline & & 0.55 R25-F0 & 5025 & 5030 & 5046 \\
\hline & & 0.55 R25-F10 & 5053 & 5085 & 5190 \\
\hline & & 0.55 R25-F15 & 5068 & 5096 & 5193 \\
\hline 2 & 1 & & At 56 days & At 72 days & At 112 days \\
\hline & & 0.40 Control & 5725 & 5800 & 5980 \\
\hline & & 0.45 R25-F0 & 5616 & 5646 & 5654 \\
\hline & & 0.45 R25-F10 & 5676 & 5763 & 5890 \\
\hline & & 0.45 R25-F15 & 5668 & 5970 & 5998 \\
\hline
\end{tabular}


Am. J. Engg. \& Applied Sci., 4 (2): 201-208, 2011

Table 6: Average modulus of elasticity

\begin{tabular}{|c|c|c|c|c|c|c|c|c|}
\hline \multirow[b]{2}{*}{ Type } & \multirow[b]{2}{*}{ Batch } & \multirow[b]{2}{*}{ ID } & \multicolumn{6}{|c|}{ Elastic Modulus $\left(\times 10^{6} \mathrm{psi}\right)$} \\
\hline & & & At 14 days & & At 28 days & & At 5 & \\
\hline \multirow{10}{*}{1} & & & Mea. & Cal. & Mea. & Cal. & Mea. & $\mathrm{Cal}$. \\
\hline & 1 & 0.50 Control & 4.02 & 3.99 & 4.02 & 4.13 & 4.02 & 4.25 \\
\hline & & $0.55 \mathrm{R} 25-\mathrm{F} 0$ & 3.86 & 4.00 & 4.02 & 4.12 & 4.02 & 4.28 \\
\hline & & 0.55 R25-F10 & 3.86 & 4.04 & 4 & 4.17 & 4 & 4.35 \\
\hline & & $0.55 \mathrm{R} 25-\mathrm{F} 15$ & 3.89 & 3.96 & 4 & 4.15 & 4 & 4.33 \\
\hline & 2 & & At 56 days & At 72 days & At 112 days & & & \\
\hline & & 0.50 Control & 4.02 & 4.28 & 4.02 & 4.28 & 4.02 & 4.28 \\
\hline & & 0.55 R25-F0 & 4.02 & 4.25 & 4.02 & 4.26 & 4.02 & 4.26 \\
\hline & & 0.55 R25-F10 & 4.00 & 4.29 & 4.01 & 4.30 & 4.02 & 4.35 \\
\hline & & $0.55 \mathrm{R} 25-\mathrm{F} 15$ & 4.00 & 4.27 & 4.01 & 4.28 & 4.02 & 4.33 \\
\hline \multirow[t]{5}{*}{2} & 1 & & At 56 days & At 72 days & At 112 days & & & \\
\hline & & 0.40 Control & 4.20 & 4.56 & 4.20 & 4.59 & 4.20 & 4.66 \\
\hline & & 0.45 R25-F0 & 4.01 & 4.48 & 4.02 & 4.49 & 4.02 & 4.49 \\
\hline & & 0.45 R $25-F 10$ & 4.01 & 4.52 & 4.02 & 4.56 & 4.10 & 4.61 \\
\hline & & 0.45 R25-F15 & 4.01 & 4.54 & 4.02 & 4.66 & 4.10 & 4.67 \\
\hline
\end{tabular}

Table 7: Average flexural strength

\begin{tabular}{|c|c|c|c|c|c|c|}
\hline \multirow[b]{2}{*}{ Type } & \multirow[b]{2}{*}{ Batch } & \multirow[b]{2}{*}{ ID. } & \multicolumn{4}{|c|}{ Flexural strength (psi) } \\
\hline & & & At 28 days & & At 56 & \\
\hline \multirow{10}{*}{1} & & & Mea. & Cal. & Mea. & Cal. \\
\hline & 1 & 0.50 Control & 725 & 521 & 768 & 536 \\
\hline & & 0.55 R25-F0 & 707 & 514 & 763 & 535 \\
\hline & & $0.55 \mathrm{R} 25-\mathrm{F} 10$ & 718 & 519 & 779 & 540 \\
\hline & & 0.55 R25-F15 & 717 & 519 & 783 & 541 \\
\hline & 2 & & At 72 days & At 112 days & & \\
\hline & & 0.50 Control & 802 & 540 & 825 & 540 \\
\hline & & 0.55 R25-F0 & 759 & 532 & 775 & 533 \\
\hline & & 0.55 R $25-F 10$ & 784 & 535 & 790 & 540 \\
\hline & & 0.55 R $25-F 15$ & 779 & 535 & 780 & 540 \\
\hline \multirow[t]{5}{*}{2} & 1 & & At 72 days & At 112 days & & \\
\hline & & 0.40 Control & 802 & 571 & 825 & 580 \\
\hline & & 0.45 R25-F0 & 759 & 564 & 775 & 564 \\
\hline & & 0.45 R25-F10 & 784 & 569 & 790 & 576 \\
\hline & & 0.45 R25-F15 & 779 & 579 & 780 & 581 \\
\hline
\end{tabular}

Effects of RCA and FA on flexural strength: Table 7 presents the analysis of the flexural strength tests. They show that there is an overall reduction of flexural strength in concrete with RCA and FA added but strength increases with the percentage of FA.

Batch 1-Type 1 with a fixed 0.55 water/cement ratio and a cure time of 28 days, the flexural strength is lower by $2.6,0.9$ and $0.9 \%$ respectively for the three concrete mixtures: ID 0.55 R25-F0, 0.55 R25-F10 and R25-F15 as compared with the control mix. This shows that concrete mixtures containing $10,15 \%$ FA gain in flexural strength by $1.7 \%$ as compared with concrete mixtures only containing RCA at long cure durations. At 56 days, the flexural strength is lower by $0.6 \%$ for concrete mixture ID $0.55 \mathrm{R} 25-\mathrm{F} 0$ and greater by $1.4,1.8 \%$ for the concrete mixtures with ID: 0.55 R25F10 and 0.55 R25-F15 respectively when compared with the control mix. At 72 days, the flexural strength is lower by $1.6 \%$ for concrete mixture with ID 0.55 R25-
F0 as compared with the control mix. Flexural strength is greater by $0.7,1.6 \%$ respectively for concrete mixture with ID 0.55 R25-F10 and 0.55 R25-F15 as compared to the 0.55 control mix. At 112 days, the flexural strength is lower by $2.8 \%$ for concrete mixture with ID $0.55 \mathrm{R} 25-\mathrm{F} 0$ and greater by $0.6,0.07 \%$ respectively for concrete mixtures with ID: 0.55 R25-F10 and 0.55 R25F15 as compared with the 0.55 control mix. This shows that concrete mixtures with FA gain in flexural strength gradually as compared with concrete mixtures containing only RCA with long cure duration.

The specimens in Type 2 at a curing time of 72 days, the flexural strength is lower by 5.8,2.3 and 3\% respectively for the three concrete mixtures: ID 0.45 R25-F0, 0.45 R25-F10 and 0.45 R25-F15 as compared with the control mix. At 112 days, the flexural strength is lower by $6.4,4.4$ and $4.5 \%$ respectively for the three concrete mixtures with ID 0.45 R25-F0, 0.45 R25-F10 and 0.45 R25-F15 as compared with the 0.45 control mix. 


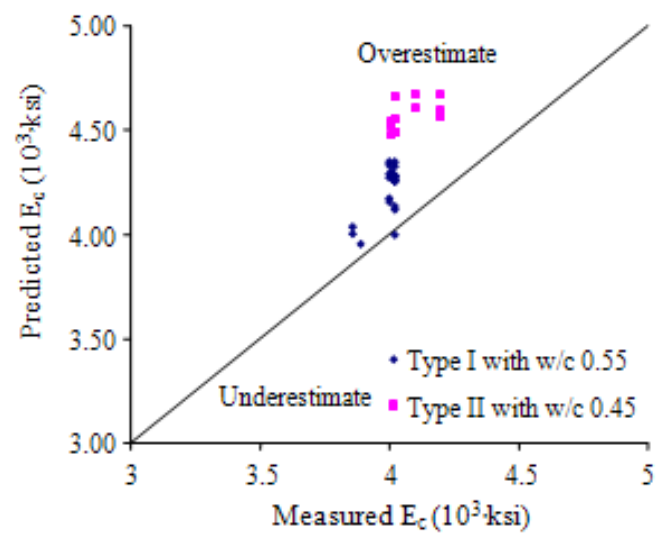

Fig. 2: Measured versus predicted elastic modulus

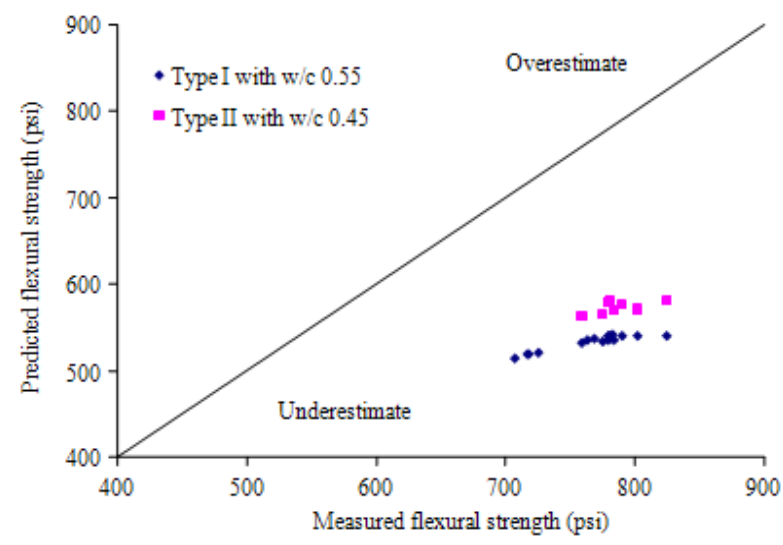

Fig. 3: Measured versus predicted flexural strength

The flexural strength was compared with the prediction $\left(\mathrm{f}_{\mathrm{r}}=7.5 \sqrt{\mathrm{f}_{\mathrm{c}}^{\prime}}, \mathrm{psi}\right)$ by ACI 318 (2008). It generally underestimated flexural strengths of experimental results as seen in Fig. 3.

\section{DISCUSSION}

Effect of RCA and FA on compressive strength: Generally, the compressive strength were decreased as containing RCA without FA in the mixes regardless the curing ages, while the development of compressive strength was observed as increasing amount of FA in the mixes. Compatible compressive strength was developed over the age of 56 days even containing the RCA in the mixes.

Effect of RCA and FA on modulus of elasticity: Concrete mixtures containing $10,15 \%$ FA exhibit a decrease in elastic modulus of $0.5 \%$ when compared with concrete mixtures containing RCA only for shorter cure durations.
Effects of RCA and FA on flexural strength: The gaining flexural strength with FA in the concrete mixes was observed for all of tests. In short, the compatible flexural strength could be obtained with concrete mixes containing RCA and FA.

\section{CONCLUSION}

This purpose of this study was to evaluate the feasibility of using concrete containing RCA and FA for use in low-modulus concrete pavement applications. Results of the laboratory testing program indicate the following conclusions.

The properties in the fresh concrete (e.g., slump, unit weight, air content and temperature) were similar in concrete mixes containing RCA and FA due to the modified water cement ratio.

The compressive strength was slightly reduced in the concrete mixes containing 25 percent RCA. This results can confirmed with other literatures. As increasing the FA in the concrete mixes containing RCA, the compressive strength steadily increased and slightly higher than that of control mixes without RCA and FA. Similar results were observed regardless with water cement ratio.

The elastic modulus slightly decreases for all three different concrete mixtures containing RCA and FA at 14, 28 days. After the age of 56 days, concrete mixtures containing RCA have the same value of elastic modulus as the control mixtures. At the age of 112 days, the elastic modulus is equal and/or slightly less than that of concrete mixtures containing RCA and FA. The computed values by the ACI 318 equation overestimate the elastic modulus in this study.

The flexural strength decreases for all concrete mixtures containing RCA and FA at 28 days in Type 1. The flexural strength is still lower after 56 days up to 112 days of cure duration for concrete mixtures containing RCA of Type 1 and Type 2 as compared to the control mix. The results indicates that the reduction of flexural strength in the concrete with RCA and FA. The flexural strength may not gain even the FA added. The experimental tests are over the computed values by the ACI 318 equation.

After analysis, it has been determined that the concretes containing RCA and FA have the same strength after 112 days of cure duration as the control $\operatorname{mix}$ at $0.55,0.45$ water/cement ratio. With the use of RCA up to $25 \%$ and FA up to $15 \%$ there will not be a significant difference (if any) in strength compared with concrete containing virgin aggregate. Thus the RCA and FA might be used in the concrete pavement. It will promote the economical and environmental benefit. 
Am. J. Engg. \& Applied Sci., 4 (2): 201-208, 2011

\section{ACKNOWLEDGMENT}

The researchers would like to graciously thank the Defense Threat Reduction Agency (DTRA) for funding of this research.

\section{REFERENCES}

Ahmed, S.F.U., N. Ahmad and H. Mihashi, 2009. Restrained shrinkage-induced cracking of light weight high performance fiber reinforced cementitious composites. Am. J. Eng. Applied Sci., 2: 775-780.

DOI: 10.3844/ajeassp.2009.775.780

Anderson, K.W., J.S. Uhlmeyer and M.A. Russell. 2009, Use of Recycled Concrete Aggregate in PCCP: Literature Search. Transportation Research Board. http://144.171.11.39/view.aspx?id=902140

Bekoe, P.A., M. Tia and M.J. Bergin, 2010. Concrete containing recycled concrete aggregate for use in concrete pavement. Trans. Res. Record. J. Trans. Res. Board., 2164: 113-121. DOI: 10.3141/216415

Chandramouli, K., P.S. Rao, N. Pannirselvam, T.S. Sekhar and P. Sravana, 2010. Chloride penetration resistance studies on concretes modified with alkali resistant glass fibers. Am. J. Applied Sci., 7: 371375. DOI: 10.3844/ajassp.2010.371.375

Hamoush, S., M. Picornell-Darder, T. Abu-Lebdeh and A. Mohamed, 2011. Freezing and thawing durability of very high strength concrete. Am. J. Eng. Applied Sci., 4: 42-51. DOI: 10.3844/ajeassp.2011.42.51

Hansen, T.C., 1999. Recycled aggregates and recycled aggregate concrete second state-of-the-art report developments 1945-1985. Mater. Struct., 19: 201246. DOI: $10.1007 / \mathrm{BF} 02472036$

Hoe, K.W. and M. Ramli, 2010. Rational mix design approach for high strength concrete using sand with very high fineness modulus. Am. J. Eng. Applied Sci., 7: 1562-1568. DOI: DOI: 10.3844/ajassp.2010.1562.1568

Kumar, D.R. and B. Vidivelli, 2010. Acrylic rubber latex in ferrocement for strengthening reinforced concrete beams. Am. J. Eng. Applied Sci., 3: 277285. DOI: $\quad$ 10.3844/ajeassp.2010.277.285

Kumaran, G.S., N. Mushule and M. Lakshmipathy, 2008. A review on construction technologies that enables environmental protection: rubberized concrete. Am. J. Eng. Applied Sci., 1: 40-44. DOI: 10.3844/ajeassp.2008.40.44
Maghsoudi, A.A. and Y. Sharifi, 2008. The serviceability considerations of HSC heavily steel reinforced members under bending. Am. J. Applied Sci., 5: 1135-1140. DOI: 10.3844/ajassp.2008.1135.1140

Mehta, P.K. and P.J.M. Monteiro, 2006. Concrete: Microstructure, Properties and Materials. 3rd Edn., The McGraw Hill, New York, ISBN: 10: 0071462899, pp: 659.

Nagaradjane, V., P.N. Raghunath and K. Suguna, 2009. Reliability of axially loaded fibre-reinforcedpolymer confined reinforced concrete circular columns. Am. J. Eng. Applied Sci., 2: 31-38. DOI: 10.3844/ajeassp.2009.31.38

http://docsdrive.com/pdfs/sciencepublications/ajea ssp/2009/31-38.pdf

http://direct.bl.uk/bld/PlaceOrder.do?UIN=134943 $193 \&$ ETOC $=$ RN\& from $=$ searchengine

Qadi, A.N.S.A., K.N.B. Mustapha, H. Al-Mattarneh and Q.N.S. AL-Kadi, 2009. Statistical models for hardened properties of self-compacting concrete. Am. J. Eng. Applied Sci., 2: 764-770. DOI: 10.3844/ajeassp.2009.764.770

Ramli, M. and K.W. Hoe, 2010. Influences of short discrete fibers in high strength concrete with very coarse sand. Am. J. Applied Sci., 7: 1572-1578. DOI: 10.3844/ajassp.2010.1572.1578

Ravichandran, A., K. Suguna and P.N. Ragunath, 2009. Strength modeling of high-strength concrete with hybrid fibre reinforcement. Am. J. Applied Sci., 6: 219-223. DOI: 10.3844/ajassp.2009.219.223

Rawshan, A.B, S.K. Satari and J.J. Pereira, 2010. Waste generation and recycling: Comparison of conventional and industrialized building systems. Am. J. Environ. Sci., 6: 383-388. DOI: 10.3844/ajessp.2010.383.388

Roshan, A.M.G., M.B. Hosseinian, H. Khalilpasha and R. Amirpour, 2010. Optimization of micro silica in light weight lika concrete. Am. J. Eng. Applied Sci., 3: 449-453. 10.3844/ajeassp.2010.449.453

Saravanan, J., K. Suguna and P.N. Raghunath, 2010. Confined high strength concrete columns: An experimental study. Am. J. Eng. Applied Sci., 3: 133-137. DOI: 10.3844/ajeassp.2010.133.137

Sirimontree, S. and J. Teerawong, 2010. Flexural behaviors of damaged full-scale highway bridge girder strengthened by external post tension. Am. J. Eng. Applied Sci., 3: 650-662. DOI: 10.3844/ajeassp.2010.650.662 